\title{
STUDI ANALISIS KOBALT SECARA KOLORIMETRI DENGAN 1-NITROSO-2-NAFTOL
}

\section{Gunawan}

Laboratorium Kimia Analitik Jurusan Kimia

F MIPA Universitas Diponegoro Semarang 50275

\begin{abstract}
ABSTRAK
Penelitian tentang studi analisis kobalt secara kolorimetri dengan 1-nitroso-2-naftol telah dilakukan. Reaksi pembentukan kompleks dilakukan pada pH 9 Hasil penelitian diperoleh kompleks kobalt yang terbentuk mempunyai bilangan koordinasi tiga Kompleks yang terbentuk mengikuti alur Hukum Beer sampai konsentrasi $410^{-4} \mathrm{M}$. Adanya ion nikel dan ion besi masing-masing sampai konsentrasi $20 \mathrm{mg} / \mathrm{L}$ dan $5 \mathrm{mg} / \mathrm{L}$, tidak memeberikan gangguan analisis, sedangkan konsentrasi besi lebih besar dari $6 \mathrm{mg} / \mathrm{L}$ menyebabkan deviasi positif.
\end{abstract}

Kata kunci: kolorimetri, kompleks kobalt, interferensi.

\begin{abstract}
The research of analysis strudy of cobalt with 1-nitroso-2-naphtol had been done specctrophotometrically. The complexation reaction was performed at $\mathrm{pH}$ of 9 . The research showed that the cobalt complex had coordination number three. The formed complex followed the Beer's Law plot until the concentration of $4.10^{-4} \mathrm{M}$. The presence of nickel and iron ions had no interferences up to concentration of $20 \mathrm{mg} / L$ for the former and $5 \mathrm{mg} / \mathrm{L}$ for the latter., while the iron ion concentration more than $6 \mathrm{mg} / \mathrm{L}$ gave positive deviation.
\end{abstract}

Keywords: Colorimetry, cobalt complex, interference.

\section{PENDAHULUAN}

Analisis kobalt dalam air atau batuan dengan kolorimetri belum ada prosedur baku, yang baku biasanya dianalisis dengan spektrofotometri serapan atom. Sehingga perlu dipelajari kemungkinan penggunaan 1nitroso-2-naftol untuk pengompleks kobalt sehingga dapat dianalisis secara kolorimetri.

Kolorimetri merupakan metoda penentuan analit (zat yang dianalisis, baik itu anion maupun kation) yang berwarna dan dibandingkan dengan larutan standar. Analit tersebut dapat dibuat berwarna dengan mengubah menjadi spesies yang berwarna (seperti $\mathrm{Mn}^{2+}$ yang tidak berwarna diubah menjadi $\mathrm{MnO}_{4}^{-}$yang berwarna dengan adanya $\mathrm{S}_{2} \mathrm{O}_{8}{ }^{"}$ )

Atau direaksikan dengan zat pembentuk warna (chromogenic agent) sehingga menjadi kompleks berwarna Analit + zat pembentuk warna $\underset{\sim}{\rightleftharpoons}$ kompleks berwarna Contoh: $\mathrm{Fe}^{3+}+\mathrm{CNS}^{-} \rightleftharpoons\left[\mathrm{Fe}(\mathrm{CNS})_{6}\right]^{=}$

Tidak berwarna merah $\mathrm{Ni}^{2+}+\mathrm{DMG} \rightleftharpoons\left[\mathrm{Ni}(\mathrm{DMG})_{2}\right]$

Tidak berwarna merah

Reaksi pembentukan kompleks merupakan reaksi pembentukan ikatan kovalen koordinasi (reaksi asam- basa Lewis), yaitu adanya atom/molekul yang menyumbangkan pasangan elektron (basa Lewis) dan atom atau ion yang menerima pasangan elektron (asam Lewis). Atom/molekul yang menyumbangkan pasangan elektron dikenal dengan sebutan ligan, yang mempunyai syarat mempunyai pasangan elektron bebas yang dapat disumbangkan ke atom penerima. Ligan dapat berupa atom/molekul yang bermuatan atau netral. Sedangkan atom/ion yang menerima pasangan elektron disebut atom/ion pusat yang mempunyai syarat harus memiliki orbital atom kosong. Atom yang bertindak sebagai atom pusat umumnya adalah ion logam transisi. Ligan yang mempunyai satu pasang elek. tron bebas (lone pair electrons) disebut ligan unidentat, sedangkan glisin mempunyai ligan bidentat. Ligan yang mempunyai lebih dari dua pasang elektron bebas disebut ligan polidentat, misalnya asam etilendiamin tetraasetat. Sedangkan ion logam yang bertindak sebagai atom pusat antara lain perak, nikel, seng, besi, tembaga, timbal, raksa, kadmium, mangan dan kobalt (Basolo, 1968).

Kobalt merupakan atom logam transisi pada sistem periodik unsur terletak pada golongan VIII B. Kobalt pada reaksi pembentukan kompleks (yang berada dalam bentuk ionnya) berperan sebagai atom pusat, sedangkan 1-nitroso-2-naftol mampu menyumbangkan dua pasang elektron bebasnya (ligan bidentat), sehingga dengan ion $\mathrm{Co}^{3+}$ bisa membentuk kompleks chelate. Ion $\mathrm{Co}^{2+}$ menyediakan orbital kosong untuk pasa- 
ngan elektron bisa $\mathrm{dsp}^{2}$ atau $\mathrm{sp}^{3}$, sedangkan $\mathrm{Co}^{3+}$ orbital kosong untuk pasangan elektron bisa $\mathrm{d}^{2} \mathrm{sp}^{3}$ atau $\mathrm{sp}^{3} \mathrm{~d}^{2}$.

Senyawa 1-nitroso-2-naftol dapat disintesis dari $a$ naftol dengan reaksi seperti pada lampiran I.

Setelah direaksikan dengan petroleum ether diperoleh 1-nitroso-2-naftol dengan titik leleh $106^{\circ} \mathrm{C}$ dan $\mathrm{Ka}$ $2.10^{-8}$ kelarutan dalam air $1,0610^{-3}$ dan $1,35 \mathrm{M}$ dalam $\mathrm{CHCl}_{3}$ (Cram, D.J. dan Hammond, G.S., 1964, dan Vogel, A.I., 1989).

\section{BAHAN-ALAT DAN METODA}

Bahan: $\alpha$-naftol, $\mathrm{NaOH}, \mathrm{H}_{2} \mathrm{SO}_{4}, \mathrm{NaNO}_{2}$, petroleum ether, $\mathrm{Co}\left(\mathrm{NO}_{3}\right)_{2} \cdot 6 \mathrm{H}_{2} \mathrm{O}, \mathrm{NiCl}_{2} \cdot 6 \mathrm{H}_{2} \mathrm{O}, \mathrm{FeCl}_{3} \cdot 6 \mathrm{H}_{2} \mathrm{O}$, akuades, $\mathrm{H}_{2} \mathrm{O}_{2}$ semuanya dalam kualitas pa E. Merck.

Alat: seperangkat spectronic-20D, labu alas bulat, pengaduk magnet, corong pisah, gelas beaker, pipet volume, pipet ukur, penangas air, termometer, desikator, oven, gelas arloji, labu takar.

\section{Metoda}

\section{Pembuatan 1-nitroso-2-naftol}

Sebanyak $10 \mathrm{~g}(0,07 \mathrm{~mol}) \alpha$-naftol dilarutkan dalam larutan hangat yang berisi $\mathrm{NaOH} 2,8 \mathrm{~g}(0,07 \mathrm{~mol}) \mathrm{da}-$ lam $120 \mathrm{~mL}$ akuades dalam labu alas bulat $500 \mathrm{~mL}$ yang dilengkapi pengaduk magnet. Campuran didinginkan sampai $0^{\circ} \mathrm{C}$ dalam pendingin es kemudian ditambah $5 \mathrm{~g}(0,0725 \mathrm{~mol})$ serbuk $\mathrm{NaNO}_{2}$. Campuran tersebut diaduk sambil ditambahkan $22 \mathrm{~g}(16,65 \mathrm{~mL}) \mathrm{H}_{2} \mathrm{SO}_{4}$ $(5,6 \mathrm{M})$ melalui corong pisah dengan waktu penambahan total 90 menit dan temperatur dijaga tetap $0^{\circ} \mathrm{C}$. Campuran diaduk selama beberapa jam dengan temperatur tetap $0^{\circ} \mathrm{C}$. Setelah reaksi berakhir endapan disaring menggunakan pompa vakum dan dicuci dengan air. Endapan 1-nitroso-2-naftol yang diperoleh berwarna kuning pucat, kemudian diletakkan dalam desikator selama 4 hari, warna endapan menjadi coklat gelap dengan titik leleh $106^{\circ} \mathrm{C}$ dan berat sekitar $11,5 \mathrm{~g}$.

\section{Pembuatan larutan standar}

Larutan standar 1-nitroso-2-naftol 1. 10-3 M. Padatan 1-nitroso-2-naftol 0,1732 g dilarutkan dalam etanol sampai volume $1 \mathrm{~L}$.

Larutan standar $\mathrm{Co}^{2+}$. Sebanyak 0,46 g Co( $\left(\mathrm{NO}_{3}\right)_{2} \cdot 6 \mathrm{H}_{2} \mathrm{O}$ dilarutkan dalam akuades sampai volume $500 \mathrm{~mL}$. Untuk mengoksidasi $\mathrm{Co}^{2+}$ menjadi $\mathrm{Co}^{3+}$ digunakan $\mathrm{H}_{2} \mathrm{O}_{2}$.
Larutan standar $\mathrm{Ni}^{2+} 1000 \mathrm{mg} / \mathrm{L}$. Sebanyak 2,0236 g $\mathrm{NiCl}_{2} \cdot 6 \mathrm{H}_{2} \mathrm{O}$ dilarutkan dalam akuades sampai volume $500 \mathrm{~mL}$

Larutan standar $\mathrm{Fe}^{3+} 1000 \mathrm{mg} / \mathrm{L}$. Sebanyak 2,4189 g $\mathrm{FeCl}_{3} .6 \mathrm{H}_{2} \mathrm{O}$ dilarutkan dalam akuades sampai volume $500 \mathrm{~mL}$

Buffer $\mathrm{Ph}$ 9. Campuran ammonia dan ammonium klorida dicampur sampai diperoleh $\mathrm{pH}$ 9,0 (dengan menggunakan $\mathrm{pH}$ meter).

\section{Studi analisis kobalt}

Penentuan panjang gelombang optimum dan $\mathrm{pH}$ optimum yang memberikan serapan maksimum. Sederet larutan kompleks dengan konsentrasi sama tetapi mempunyai $\mathrm{pH}$ bervariasi. Kemudian diukur serapannya pada daerah tampak dengan variasi panjang gelombang.

Penentuan banyaknya mol ligan dalam senyawa kompleks dengan metoda perbandingan mol. Sederet larutan kompleks yang mengandung penyusun dengan konsentrasi tetap (1-nitroso-2-naftol) sedangkan $\mathrm{Co}^{3+}$ divariasi. Serapannya diukur pada panjang gelombang optimum

Studi lineraritas kurva standar. Sederet larutan kompleks dengan konsentrasi kobalt bervariasi diukur serapannya pada panjang gelombang optimum.

Studi interferensi. Interferensi nikel dan besi dipelajari dengan seri larutan kompleks dengan konsentrasi tetap tetapi konsentrasi nikel dan besi bervariasi, kemudian diukur serapannya pada panjang gelombang optimum.

\section{Hasil dan Pembahasan}

\section{Pembahasan}

Studi analisis kompleks kobalt-1-nitroso-2-naftol dari pengamatan penentuan panjang gelombang dan $\mathrm{pH}$ seperti diberikan oleh kurva pada gambar 1. Dari kurva tersebut terlihat bahwa senyawa kompleks yang terjadi mempunyai serapan maksimum pada panjang gelombang $405 \mathrm{~nm}$ dan dalam suasana basa antara 811. Dalam suasana asam kompleks tersebut mempunyai serapan pada panjang gelombang yang sama dengan serapan dari ligan sehingga akan kesulitan dalam pengamatannya. Pada penelitian ini selanjutnya digunakan $\mathrm{pH} 9$. 


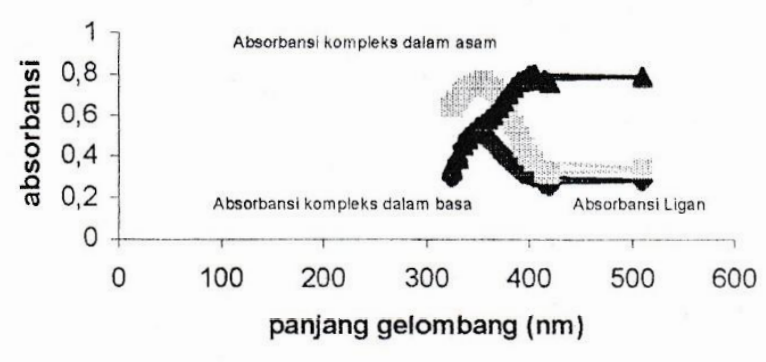

Gambar 1 Penentuan panjang gelombang pada $\mathrm{pH}$ optimum

Banyaknya ligan yang berikatan dengan ion dari atom pusat dalam senyawa kompleks kobalt-1-nitroso-2-naftol ditentukan dengan metoda perbandingan mol. Dari kurva gambar 2 terlihat kurva mulai berubah arah/ slop pada fraksi mol 0,7355, sehingga jumlah ligan yang terikat oleh atom pusat adalah $0,7355 / 0,265=2,77$ $\cong 3$. Dengan jumlah ligan 1-nitroso-2-naftol sebanyak tiga buah, karena merupakan ligan bidentat maka bentuk geometri molekul chelate tersebut ada-lah oktahedral.

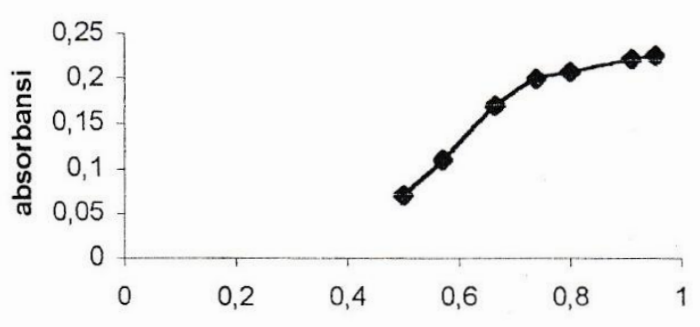

Fraksi mol ligan 1-nitroso-2-naftol

Gambar 2. Penentuan jumlah ligan yang terikat oleh $\mathrm{Co}^{31}$.

Harga linearitas $\mathrm{Co}(1 \text {-nitroso-2-naftol })_{3}$ dari gambar 3 diperoleh sampai konsentrasi kobalt $410^{-5} \mathrm{M}$ dengan $\mathrm{R}^{2}=0,9943$ (Gambar 3b), setelah konsentrasi itu memberikan linearitas yang tidak baik $\left(R^{2}=0,9316\right)$ (gambar 3a). Sehingga pada konsentrasi sampai $410^{-5} \mathrm{M}$ dapat digunakan untuk analisis kuantitatif, karena mengikuti Alur Hukum Beer.

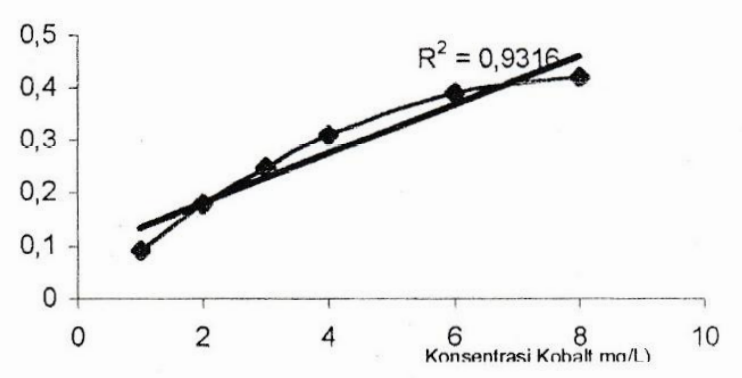

(a)

No. Artikel : JKSA, Vol VI, No. 1, 2003 


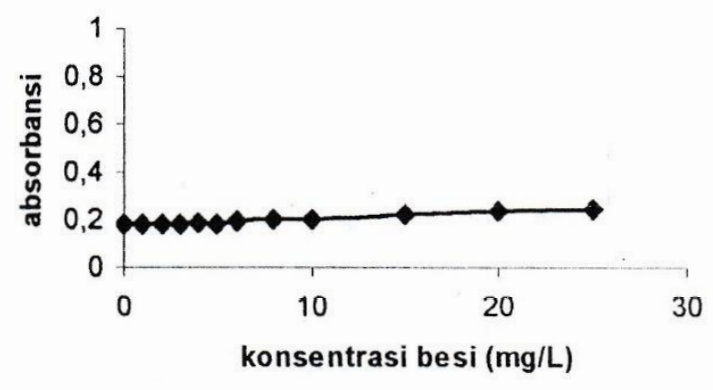

Gambar 5 Pengaruh ion besi terhadap absorbansi kompleks kobalt.

\section{KESIMPULAN}

Senyawa 1-nitroso-2-naftol dapat membentuk kompleks dengan kobalt yang mempunyai warna kuning kecoklatan yang cukup stabil. Kompleks yang terbentuk mematuhi alur Hukum Beer sampai konsentrasi 4 $10^{-5} \mathrm{M}$. Adanya nikel dan besi dalam konsentrasi yang kecil tidak mengganggu analsisis kobalt dengan pengompleks 1-nitroso-2-naftol.

\section{UCAPAN TERIMA KASIH}

Ucapan terima kasih, penulis sampaikan kepada Kepala Laboratorium Kimia Analitik Universitas Gadja Mada atas bantuan dan sarana yang telah diberikan selama penelitian ini.

\section{PUSTAKA}

1. APHA (American Public Heath Associations), 1986, Standard Methods: For Examination of Water and Waste Water, $14^{\text {th }}$ ed., APHA, Washington D.C.
2. Basset, J., Denny, R.C., Jefferey, G.H. dan Mendham, J., Vogel's Textbook of Macro and Semimicro Quantitative Inorganic Analysis, $5^{\text {th }}$ ed., Longman Group Ltd., London.

3. Basolo, F., 1968, Coordinaton Chemistry, John Wiley and Sons, New York.

4. Cram, D.J. dan Hammond, G.S., 1964, Organic Chemsistry, McGraw Hill Book Co. Inc., New York.

5. Pecsock, R.L., et al., Modern Methods of Chemical Analysis, $1968,2^{\text {nd }}$ edition, John Wiley \& Sons, New York.

6. Sandell, E., B. dan H Onishi, 1978, Colorimetric Determination of Traces of Metals, $4^{\text {th }}$ edition, Interscience, New York.

7. Skoog, D.A., 1985, Principles of Instrumental Analysis, $3^{\text {rd }}$ edition, Saunders College Publishing, Philadelphia.

8. Vogel, A.I., 1989, A Textbook of Organic Chemsitry Inchuding Qualitative Organic analysis, $1^{\text {st }}$ ed., Longman Green and Co., London.

9. Bhatt, R., Mehta, C., Groswani, A.K. and Purohit, DN., Orient. J. Chem., 1993, 9(2), 174-5 (Eng). 
- Lampiran I

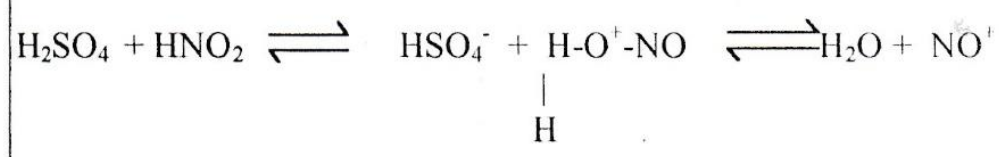

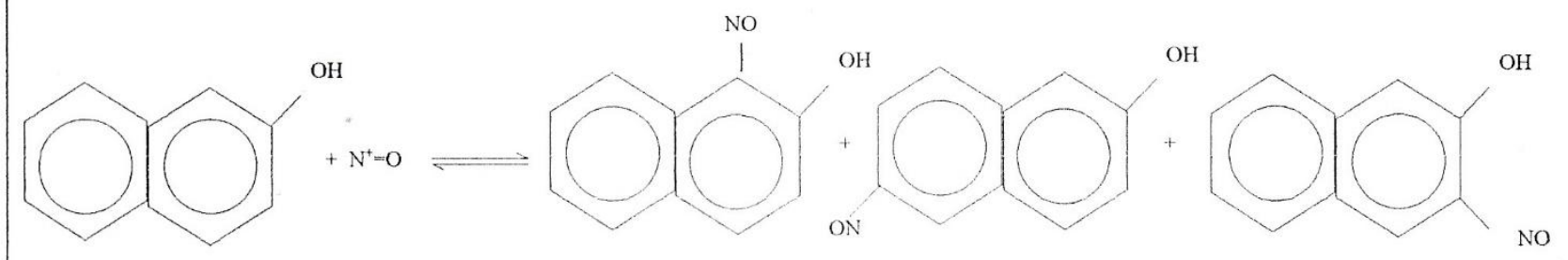

